\title{
Comparison of the Magnesium Alterations after Erythropoietin and U-74389G Process
}

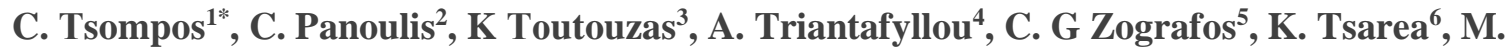 \\ Karamperi $^{7}$ A. Papalois ${ }^{8}$ \\ ${ }^{1}$ ConstantinosTsompos: Department of Gynecology, Anticancer Hospital of Thessaloniki "Theageneio" \\ Thessaloniki, Hellas \\ ${ }^{2}$ ConstantinosPanoulis: Department of Obstetrics \& Gynecology, Aretaieion Hospital, Athens University, \\ Athens, Attiki, Hellas \\ ${ }^{3}$ Konstantinos Toutouzas: Department of Surgery, Ippokrateion General Hospital, Athens University, Athens, \\ Attiki, Hellas \\ ${ }^{4}$ AggelikiTriantafyllou: Department of Biologic Chemistry, Athens University, Athens, Attiki, Hellas \\ ${ }^{5}$ C. G Zografos: Department of Surgery, Ippokrateion General Hospital, Athens University, Athens, Attiki, Hellas \\ ${ }^{6}$ KalliopiTsarea: Experimental Research Centre ELPEN Pharmaceuticals, S.A. Inc., Co., Pikermi, Attiki, Hellas \\ ${ }^{7}$ Maria Karamperi: Experimental Research Centre ELPEN Pharmaceuticals, S.A. Inc., Co., Pikermi, Attiki, Hellas \\ ${ }^{8}$ Apostolos Papalois: Experimental, Educational and Research Center ELPEN \\ European University Cyprus, School of Medicine
}

*Corresponding Author: TsomposConstantinos, Department of Gynecology Anticancer Hospital of Thessaloniki "Theageneio" AlexandrouSymeonidi street, Thessaloniki Hellas .

\begin{abstract}
Aim: This study calculated the effects on serum magnesium (Mg) levels, after treatment with either of 2 drugs: the erythropoietin (Epo) and the antioxidant lazaroid (L) drug U-74389G. The calculation was based on the results of 2 preliminary studies, each one of which estimated the certain influence, after the respective drug usage in an induced ischemia reperfusion (IR) animal experiment.

Materials and methods: The 2 main experimental endpoints at which the serum $\mathrm{Mg}$ levels were evaluated was the 60th reperfusion min (for the groups $A, C$ and $E$ ) and the 120th reperfusion min (for the groups $B, D$ and F). Specially, the groups $A$ and $B$ were processed without drugs, groups $C$ and $D$ after Epo administration; whereas groups $E$ and $F$ after the L administration.

Results: The first preliminary study of Epo presented a non significant hypomagnesiemic effect by $0.19 \% \pm 0.10 \%$ ( $p$-value $=0.9197)$. However, the second preliminary study of $U-74389 G$ presented a significan thypermagnesiemic effect by $0.36 \% \pm 1.66 \%$ ( $p$-value=0.8228). These 2 studies were co-evaluated since they came from the same experimental setting. The outcome of the co-evaluation was that L is 1.823808-fold [1.806514 - 1.841268] more hypermagnesiemic than Epo (p-value=0.0000).
\end{abstract}

Conclusion: The anti-oxidant capacities of $U-74389 G$ ascribe1.823808-fold more hypermagnesiemic effects than Epo (p-value=0.0000).

Keywords: : ischemia; erythropoietin; U-74389G; serum magnesium levels; reperfusion

\section{INTRODUCTION}

The lazaroid U-74389G (L) may be not famous for itshypermagnesiemic ${ }^{1}$ capacity (p-value $=0.8228$ ). U-74389G as a novel antioxidant factor, implicates exactly only 261 published studies. The ischemia reperfusion (IR) type of experiments was noted in $19.15 \%$ of these studies. A tissue protective feature of U-74389G was obvious in these IR studies. The U-74389G chemically known as 21-[4-(2,6-di-1pyrrolidinyl-4-pyrimidinyl)-1-piperazinyl]-pregna-1,4,9(11)-triene-3,20-dione maleate salt is an antioxidant complex, which prevents the lipid peroxidation either iron-dependent, or arachidonic acidinduced one. Animal kidney, liver, brain microvascular endothelial cells monolayers and heart models were protected by U-74389G after IR injury. U-74389G also attenuates the leukocytes; down- 
regulates the proinflammatory gene; treats the endotoxin shock; produces cytokine; enhances the mononuclear immunity; protects the endothelium and presents antishock property.

Erythropoietin (Epo) even if is not famous for its hypomagnesiemic ${ }^{2}$ action (p-value=0.9197), it can be used as a reference drug for comparison with U-74389G. Although Epo is met in over 31,312 published biomedical studies, only a 3.68\% of them negotiate the known type of IR experiments. Nevertheless, Epo as a cytokine, it is worth of being studied about its effects on serum magnesium $(\mathrm{Mg})$ levels too. This experimental work tried to compare the effects of the above drugs on a rat induced IR protocol. They were tested by calculating the serumMglevels alterations.

\section{Materials ANd Methods}

\subsection{Animal Preparation}

The Vet licenses under 3693/12-11- 2010 \& 14/10-1-2012 numbers, the granting company and the experiment location are mentioned in preliminary references ${ }^{1,2}$. The human animal care of Albino female Wistar rats, the 7 days pre-experimental ad libitum diet, the non-stop intra-experimental anesthesiologic techniques, the acidometry, the electrocardiogram, the oxygen supply and postexperimental euthanasia are also described in preliminary references. Rats were 16 - 18 weeks old. They were randomly assigned to six (6) groups consisted in $\mathrm{N}=10$. The stage of 45 min hypoxia was common for all 6 groups. Afterwards, reperfusion of $60 \mathrm{~min}$ was followed in group A; reperfusion of $120 \mathrm{~min}$ in group B; immediate Epo intravenous (IV) administration and reperfusion of $60 \mathrm{~min}$ in group C; immediate Epo IV administration and reperfusion of $120 \mathrm{~min}$ in group D; immediate U74389G IV administration and reperfusion of $60 \mathrm{~min}$ in group E; and immediate U-74389G IV administration and reperfusion of $120 \mathrm{~min}$ in group $\mathrm{F}$. The dose height assessment for both drugs are described at preliminary studies as $10 \mathrm{mg} / \mathrm{Kg}$ body mass.

Ischemia was caused by laparotomic clamping the inferior aorta over renal arteries with forceps for 45 min. The clamp removal was restoring the inferior aorta patency and reperfusion. After exclusion of the blood flow, the protocol of IR was applied, as described above for each experimental group. The drugs were administered at the time of reperfusion; through inferior vena cava catheter. The Mg levels were determined at 60th min of reperfusion (for $\mathrm{A}, \mathrm{C}$ and $\mathrm{E}$ groups) and at 120th min of reperfusion (for B, D and F groups). Along, non- relation was raised between $\mathrm{Mg}$ values with animals' mass ( $\mathrm{p}$ value $=0.9551)$.

\section{STATistical AnAlysis}

Table 1 presents the (\%) hypomagnesiemic influence of Epo regarding reoxygenation time. Also, Table 2 presents the $(\%)$ hypermagnesiemic influence of U-74389G regarding reperfusion time. Chisquare tests were applied using the ratios which produced the $(\%)$ results per endpoint. The outcomes of chi-square tests are depicted at Table 3.

Table1. The (\%) hypomagnesiumic influence of erythropoietin in connection with reperfusion time

\begin{tabular}{|c|c|c|}
\hline Hypomagnesiumia \pm SD & Reperfusion time & p-value \\
\hline$+1.00 \%+16.80 \%$ & $1 \mathrm{~h}$ & 0.8596 \\
\hline$-1.09 \% \pm 13.06 \%$ & $1.5 \mathrm{~h}$ & 0.7248 \\
\hline$-3.19 \% \pm 10.32 \%$ & $2 \mathrm{~h}$ & 0.3729 \\
\hline$+4.22 \%+13.14 \%$ & reperfusion & 0.1794 \\
\hline$-0.19 \% \pm 0.10 \%$ & interaction & 0.9197 \\
\hline
\end{tabular}

Table2. The (\%) hypermagnesiumicinfluence of $U-74389 G$ in connection with reperfusion time

\begin{tabular}{|c|c|c|}
\hline Hypermagnesiumia + SD & Reperfusion time & p-value \\
\hline$+1.33 \%+11.02 \%$ & $1 \mathrm{~h}$ & 0.7033 \\
\hline$-0.28 \% \pm 12.36 \%$ & $1.5 \mathrm{~h}$ & 0.9171 \\
\hline$-1.90 \%+16.81 \%$ & $2 \mathrm{~h}$ & 0.7161 \\
\hline$+4.28 \%+11.40 \%$ & reperfusion & 0.1074 \\
\hline$+0.36 \% \pm 1.66 \%$ & interaction & 0.8228 \\
\hline
\end{tabular}

Table 3: The U-74389G / erythropoietin magnesium alterations efficacies after chi-square tests application

\begin{tabular}{|c|c|c|c|c|}
\hline Odds ratio & \multicolumn{2}{|c|}{ [95\% Conf. Interval] } & p-values & Endpoint \\
\hline 1.331108 & 1.324786 & 1.33746 & 0.0000 & $1 \mathrm{~h}$ \\
\hline 0.2605466 & .2587177 & .2623884 & 0.0000 & $1.5 \mathrm{~h}$ \\
\hline
\end{tabular}




\begin{tabular}{|c|c|c|c|c|}
\hline 0.5961915 & .5942638 & .5981254 & 0.0000 & $2 \mathrm{~h}$ \\
\hline 1.013227 & 1.010824 & 1.015635 & 0.0000 & reperfusion \\
\hline 1.823808 & 1.806514 & 1.841268 & 0.0000 & interaction \\
\hline
\end{tabular}

\section{RESUlts}

The successive application of chi-square tests revealed that U-74389G caused hypermagnesiemiaby1.331108-fold [1.324786 - 1.33746] more than Epo at $1 \mathrm{~h}$ (p-value=0.00007), by 0.2605466 -fold [0.2587177 - 0.2623884] less hypomagnesiemicthan Epo at 1.5h ( $\mathrm{p}$-value=0.0000), by 0.5961915 -fold [0.5942638 - 0.5981254] less hypomagnesiemicthan Epo at $2 \mathrm{~h}$ ( $\mathrm{p}$-value $=0.0000$ ), by 1.013227 -fold [1.010824 - 1.015635] more hypermagnesiemic (p-value $=0.0000$ ) without drugs andby 1.823808 -fold [1.806514 - 1.841268] morehypermagnesiemicthan Epo whether all variables have been considered ( $\mathrm{p}$-value $=0.0000)$.

\section{DISCUSSION}

The unique available study investigating thehypermagnesiemiceffect of U-74389G was the preliminary one ${ }^{1}$. Although the most famous activities of neuroprotection and membrane-stabilization properties, it accumulates in the cell membrane, protecting vascular endothelium from peroxidative damage but hardly penetrates the blood-brain barrier. It elicits a beneficial effect in ototoxicity and Duchenne muscular dystrophy. It increases $\gamma$ gt, superoxide dismutase (SOD) and glutathione (GSH) levels in oxygen-exposed cells. It treats septic states and acts as immunosuppressant in flap survival. It prevents the learning impairments, it delays the early synaptic transmission decay during hypoxia improving energetic state of neurons. It shows antiproliferative properties on brain cancer cells and is considered as a new promising anti inflammatory drug for the treatment of reperfusion syndrome in IR injuries.

The same authors confirmed ${ }^{2}$ the short-termhypomagnesiemiceffect of Epo preparations in non iron deficient individuals. Lee MY et al determined ${ }^{3}$ changes in blood $\mathrm{Mg}^{2+}$ and $\mathrm{tMg}$ after hemorrhage identifying mechanism and origin of the changes in blood $\mathrm{Mg}^{2+}$. Hemorrhagic shock produced significant increases in blood $\mathrm{Mg}^{2+}$, but significant decreases in RBC tMg. During hemorrhagic shock, $\mathrm{K}^{+}$, anion gap, and BUN showed significant positive correlations with changes in blood $\mathrm{Mg}^{2+}$ level, while $\mathrm{Ca}^{2+}, \mathrm{pH}$, and $\mathrm{T}-\mathrm{CHO}$ were correlated with $\mathrm{Mg}^{2+}$ in a negative manner. Thus, hemorrhagic shock induced an increase in both blood-free $\mathrm{Mg}^{2+}$ and $\mathrm{tMg}$, resulted from $\mathrm{Mg}^{2+}$ efflux from metabolic damaged cell with acidosis and ATP depletion in rats. Wang AF et al found ${ }^{4}$ potassium, calcium, magnesium and to some extent, boron and zinc concentrations decreased in both Betula species and additionally manganese in B. pendula likely connected with impaired root functioning, which was not yet fully recovered from GW. Chubanov V et al uncovered ${ }^{5}$ new cellular functions of the transient receptor potential cation channel subfamily M member 7 (TRPM7) in situ including its crucial role in $\mathrm{Ca}^{2+}$ signaling and $\mathrm{Ca}^{2+}$ dependent cellular processes. Genetic inactivation of this bifunctional protein revealed its crucial role in $\mathrm{Ca}^{2+}$ signalling, $\mathrm{Mg}^{2+}$ metabolism, immune responses, cell motility, proliferation and differentiation. Reilly-O'Donnell B et al suggested ${ }^{6}$ that dysregulated $\mathrm{Zn}^{2+}$ homeostasis alters the function of both RyR2 and MG23 and that both ion channels play a key role in diastolic SR $\mathrm{Ca}^{2+}$ leakage in $\mathrm{H} 9 \mathrm{C} 2$ cells exposed to ischemic conditions. Koning $\mathrm{G}$ et al noticed $^{7}$ that mRNAs/miRNAs is involved in mitochondrial function and metabolism were modulated by $\mathrm{MgSO}_{4}$. Metabolomic analysis $\left(\mathrm{H}^{+}-\mathrm{NMR}\right)$ disclosed that $\mathrm{MgSO}_{4}$ attenuated hypoxia-ischemia (HI)-induced increases in succinate and prevented depletion of high-energy phosphates. $\mathrm{MgSO}_{4}$ pretreatment preserved mitochondrial respiration, reducing ROS production and inflammation after HI. Therefore, we propose that $\mathrm{MgSO}_{4}$ evokes preconditioning via induction of mitochondrial resistance and attenuation of inflammation in seven-day-old rats. Poore LA et al diagnosed ${ }^{8}$ urolithiasis, with uroliths identified as magnesium calcium phosphate carbonate in composition in a hand-reared 5-month-old steenbok. Groom KM et al used ${ }^{9}$ of peripartum maternal administration of magnesium sulphate for neuroprotection and corticosteroids for fetal lung maturity, to prevent adverse neonatal outcomes. Wolf $\mathrm{A}$ et al included ${ }^{10}$ the delta opioid receptor agonist D-Ala-Leu-enkephalin (DADLE), the gasotransmitter hydrogen sulfide, combinations of adenosine, lidocaine, and magnesium (ALM) or D-beta-hydroxybutyrate and melatonin (BHB/M) and therapeutic hypothermia in hibernation as a treatment of hemorrhagic shock. Koning $G$ et al resulted ${ }^{11}$ in a transient serum $\mathrm{Mg}^{2+}$ concentration elevation at $3 \mathrm{~h}$ post i.p. injection), reduced brain injury by $74 \%$ in grey matter and $64 \%$ in white matter after $\mathrm{MgSO}_{4}$ administration i.p. $24 \mathrm{~h}$ prior to the induction of $\mathrm{HI} . \mathrm{MgSO}_{4}$ 
provides a marked preconditioning protection both in postnatal day 4 and in postnatal day 5 in mice. Seyama $\mathrm{T}$ et al attenuated ${ }^{12}$ the loss of premyelinating oligodendrocytes (pre-OL) markers, such as myelin basic protein and Olig2, in ipsilateral pericallosal white matter and decreased the number of CD-68-positive microglia and TUNEL-positive cells in vivo; also inhibited lactate dehydrogenase release from pre-OL induced by oxygen glucose deprivation in vitro after antenatal maternal pretreatment with $\mathrm{MgSO}_{4}$ in a neonatal rat model. Mu YP et al found ${ }^{13}$ that increasing the magnesium concentration attenuates vasoconstriction and improves vasodilatation via release of nitric oxide. Pulmonary hypertension is associated with endothelial dysfunction resulting in the suppression of magnesium modulation of vasodilatation. Magnesium regulates vascular functions by altering the vascular responses to vasodilator and vasoactive agonists and affects endothelial function by modulating endothelium-dependent vasodilatation in hypertension. Removal of extracellular magnesium suppressed vasoreactivity of pulmonary hypertension (PA)s. A high concentration of magnesium $(4.8 \mathrm{~mm})$ inhibited ET-1-induced vasoconstriction in endothelium-intact or endotheliumdisrupted pulmonary arterial (PA)s of normoxic and chronic hypoxia $(\mathrm{CH})$-treated mice, and enhanced the ACh-induced production of NO in PAs of normoxic mice. Moreover, magnesium enhanced ACh-induced vasodilatation in PAs of normoxic mice. Hence, in this study we demonstrated that increasing the magnesium concentration can attenuate the ET-1-induced contractile response. Bennet $\mathrm{L}$ et al affirmed that $\mathrm{MgSO}_{4}$ significantly reduced ${ }^{14}$ the total duration, number of seizures, seizure amplitude, average seizure burden, the total number of seizures $(\mathrm{P}<0.001)$, peak seizure amplitude $(\mathrm{P}<0.05)$ and seizure burden $(\mathrm{P}<0.005)$ after hypoxia-ischaemia. Finally, seizures showed a circadian profile with peak seizures between 04.00 and $06.00 \mathrm{~h}$ on the first and second day post-UCO. Collectively, these results suggest that $\mathrm{MgSO}_{4}$ may have utility in treating perinatal seizures and has sexually dimorphic effects in preterm fetal sheep. Chollat $\mathrm{C}$ et al decreased the induced lesions' sizes and inflammatory cytokine levels, prevented cell death, and improved long-term behavior and reduced risks of cerebral palsy after antenatal magnesium sulfate preconditioning therapy in hypoxia models, including ${ }^{15}$ hypoxia-ischemia, inflammation, and excitotoxicity in various species (mice, rats, pigs). Dhillon SK et al gave ${ }^{16}$ treatments such as antenatal glucocorticoids and magnesium sulphate to reduce the risk of death and complications after preterm birth in mothers who are at risk of premature delivery and have high rates of diabetes and antepartum infection/inflammation. Samsonia $M$ et al have shown ${ }^{17}$ factors such as - enhancement of the antioxidant systems of neurons by acetylcysteine, inhibition of glutamate excitotoxicity by lamotrigine and correction of ion stress by magnesium ions, critically increase the time prior to apnea. Accordingly, the combination of magnesium sulfate, lamotrigine and acetylcysteine is able to protect brain cells from the damaging effects of oxygen-glucose deprivation and can be effectively used for pharmacological correction of hypoxic brain damage in acute ischemic stroke. Meloni BP et al indicated ${ }^{18}$ that magnesium is only neuroprotective when combined with post-ischemic hypothermia in cerebral ischemia models. Ogunyemi D et al associated untreated anxiety/depression with magnesium exposure $(\mathrm{aOR}=1.82)$ for independent maternal outcomes in subjects ${ }^{19}$ more likely being Non-Hispanic Whites, using tobacco, public insurance and illegal substances, unmarried, and having medical complications of pregnancy. Kumar $\mathrm{V}$ et al found calcium, magnesium, and phosphorous amounts decreased but the strongest decline was $\operatorname{seen}^{20}$ for potassium, whereas, photosynthesisrelated parameters were hardly affected, thus accumulated carbohydrates under all stresses and anthocyanins under Hpx exclude carbohydrate limitation in rosettes. Daher I et al noted that $\mathrm{MgSO}_{4}$ prevented ${ }^{21}$ sensorimotor alterations in pups, with the same efficacy in males and females, displayed anti-apoptotic and anti-inflammatory effects without deleterious side effects, tended to prevent these motor and cognitive deficits only in females, while it prevented global brain tissue damage in both sexes. Liu $\mathrm{Y}$ et al ${ }^{22}$ directly removed the intratumoral oxygen via the oxidation reactions of $\mathrm{Mg}_{2} \mathrm{Si}$ nanoparticles and later efficiently block the rapid reoxygenation via tumor blood vessels by the resultant $\mathrm{SiO}_{2}$ microsheets for cancer starvation therapy. Chollat $\mathrm{C}$ et al found the resulting lesion sizes and inflammatory cytokine levels decreased ${ }^{23}$, prevented cell death, and improved long-term cognitive and motor behaviours in models of hypoxia, hypoxia-ischemia, inflammation, and excitotoxicity after magnesium sulphate preconditioning in various animal species. However, antenatal magnesium sulphate as a neuroprotectant showed prevention of $\mathrm{CP}$ at 2 years in infants born preterm when administered to females at risk of imminent preterm birth in humans. Plush $\mathrm{K}$ et al tended ${ }^{24}$ to find reduced the negative impacts of birth hypoxia, higher vitality scores immediately after birth $(\mathrm{p}<$ 
0.10), quicker to colostrum suck and higher day one blood glucose concentrations in Mg piglets than Cont piglets $(\mathrm{p}<0.05)$ during the peri-natal period. Dumanska $\mathrm{H}$ et al observed ${ }^{25}$ hypoxia-induced reduction of voltage-dependent magnesium blockade of evoked $\mathrm{N}$-methyl-D-aspartate receptor (NMDA) response in retinocollicular synaptic transmission. Bagheri $G$ et al revealed ${ }^{26}$ that MS reduced the number and intensity of necrotic insults. The Bax/Bcl2 ratio and malondialdehyde (MDA) levels were significantly decreased in a dose-dependent manner in the MS-treated rats compared with the positive control group, while a significant dose-dependent increase in Akt expression, a pro-survival protein, was observed. In addition, MS administration reduced pro-apoptotic indice levels, ameliorated histological insults, favorably modulated oxidative status and increased Akt expression levels, indicating a possible neuroprotective effect in the case of $\mathrm{CO}$ poisoning resulting in protecting against $\mathrm{CO}$-induced cerebral injury in male Wistar rats. Lisukha LM et al determined ${ }^{27}$ the content of magnesium $(\mathrm{Mg} 2+)$ electrolytes having a multidirectional signi-ficance in different age groups in non-stimulated mixed saliva of children, with disorders of autonomous nervous system (ANS), who were born and are permanently residing at radioactive contaminated territories after application of intermittent normo-baric hypoxia (INH) of sanogenic level. Adam GO et al revealed ${ }^{28}$ that the levels of magnesium $(\mathrm{Mg} 2+)$, and calcium $(\mathrm{Ca} 2+)$ were significantly decreased whereas $\mathrm{Ca} 2+/ \mathrm{Mg} 2+$ were significantly increased than those found pre toxemia induction in acute lipopolysaccharide (LPS)-toxemia models. Li T et al showed ${ }^{29}$ that MLB prevented the elevation in right ventricular systolic pressure and the increase in ratio of wall thickness to vessel external diameter of pulmonary arteries in PAH rats, attenuated phenotypic transformation of PASMCs (decrease in $\alpha$-smooth muscle actin while increase in osteopontin), accompanied by downregulation of NADPH oxidase (NOX) (NOX2 and NOX4) protein levels, decrease of ROS and $\mathrm{H}_{2} \mathrm{O}_{2}$ production, and suppression of the phosphorylation of ERK. Pradhan T et al significantly related ${ }^{30}$ the mortality with the number of seizure episodes and time interval between seizure onset and administration of magnesium sulphate. Early detection of hypertension and management with magnesium sulphate for eclampsia can help to minimize the maternal and fetal adverse outcomes in patients with eclampsia. Lin $\mathrm{P}$ et al noticed that magnesiumlithospermate B (MLB) can promote ${ }^{31}$ renal microcirculation, improves renal function, fibrosis and inflammation and significantly reduces $24 \mathrm{hUp}, \mathrm{Scr}, \mathrm{BUN}$, SBP and DBP levels. The expression of FN, Col-I, CTGF and IL-6 were down-regulated by MLB treatment whereas significantly increased RBF. MLB reversed the expression of nNOS (neuronal nitric oxide synthase), HIF-1 $\alpha$ (hypoxia inducible factor-1) and VEGF in rats with CRF in the remnant kidney with CRF. Xu L et al measured ${ }^{32}$ increased proliferation with $\mathrm{Mg}$ extracts under hypoxia but not under normoxia. Under normoxia and with Mg extracts, HUVEC migration exhibited a bell-shaped curve. Under normoxia and increased Mg concentrations, a general negative effect was measured on early (migration) and late (tubulogenesis) angiogenesis; as magnesium degradation is an oxygen-dependant process in vitro in human primary endothelial cells.Li $\mathrm{T}$ et al showed ${ }^{33}$ hypertrophic features (increases in the ratio of RV weight to tibia length, cellular size, and hypertrophic marker expression), accompanied by upregulation in expression of NADPH oxidases (NOX2 and NOX4) and vascular peroxidase 1 (VPO1), increases in hydrogen peroxide $\left(\mathrm{H}_{2} \mathrm{O}_{2}\right)$ and hypochlorous acid $(\mathrm{HOCl})$ production and elevation in phosphorylation levels of ERK; attenuated by treating rats with Magnesium lithospermate B (MLB) in hypoxic pulmonary arterial hypertension $(\mathrm{PAH}) \mathrm{SD}$ rats.Solevåg $\mathrm{AL}$ et al targeted ${ }^{34}$ the acute brain injury in neonatal asphyxia phase after allopurinol, melatonin, noble gases such as xenon and argon, and magnesium administration also.Xing $\mathbf{J}$ et al reported ${ }^{35}$ the transient receptor potential melastatin 7 (TRPM7) as an endogenous magnesium channel to promote the proliferation of SMCs. The TRPM7 currents and intracellular magnesium level in PASMCs were also reduced by pulmonary arterial hypertension (PAH) stimuli. Functionally, TRPM7 inhibition with waixenicin A or knockdown promoted and reversely, its overexpression inhibited the proliferation and apoptosis resistance of PASMCs in Sprague-Dawley rats.Lingam I et al noticed ${ }^{36}$ that $\mathrm{MgSO}_{4}$ bolus and infusion doubled serum magnesium (0.72 vs $1.52 \mathrm{mmol} / \mathrm{L})$ with modest (16\%) rise in CSF. In Mg+HT compared with HT, there was overall reduced cell death $(p=0.01)$ and increased oligodendrocytes $(p=0.002)$ in a piglet model of term neonatal encephalopathy. Wagner $\mathrm{S}$ et al generated $^{37}$ an integrated picture of the physiological response to progressing hypoxia monitoring cytosolic dynamics of magnesium adenosine 5'triphosphate, free calcium ion concentration, $\mathrm{pH}, \mathrm{NAD}$ redox status, and glutathione redox status in parallel, linked to transcriptional and metabolic responses.Mi $\mathrm{F}$ et al observed ${ }^{38}$ that $\mathrm{Mg}^{2+}$ protected 
HT22 cells against hypoxia-induced damages by upregulating microRNA-221 (miR-221) and NGF in mouse hippocampal HT22 cells.El Farargy MS et al assessed ${ }^{39}$ that $\mathrm{MgSO}_{4}$ may have an added effect for the reduction in brain injury through the expression of S100-B, a marker of brain injury, in neonates infants with HIE who are receiving melatonin. $\mathrm{Xu} \mathrm{L}$ et al noticed ${ }^{40}$ that $\mathrm{Mg}$ degradation products increased human umbilical cord perivascular (HUCPV) migration, remarkably increased cytokines (e.g., c-c motif chemokine ligand 2 and vascular endothelial growth factor) and MSC mineralization, decreased and increased the mesenchymal stem cells (MSC) proliferation in transwell and in heterotypic-contact coculture, respectively in transwell under hypoxia.

According to above, table 3 shows that U-74389G has 1.823808-fold [1.806514 - 1.841268] more hypermagnesiemic than Epo whether all variables have been considered ( $\mathrm{p}$-value $=0.0000)$; a trend attenuated along time, in Epo non-deficient rats. A meta-analysis of these ratios from the same experiment, for 29 other seric variables, provides comparable results (table 4$)^{41,42}$.

Table4. A U-74389G / erythropoietin efficacies ratios meta-analysis on 29 hematologic variables ${ }^{41,42}$.

\begin{tabular}{|c|c|c|c|c|c|c|c|c|c|c|}
\hline $\begin{array}{c}\text { Endpoin } \\
\text { t } \\
\text { Variable }\end{array}$ & 1h & p-value & $1.5 \mathrm{~h}$ & $\begin{array}{c}\text { p- } \\
\text { value }\end{array}$ & $2 \mathrm{~h}$ & $\begin{array}{c}\text { p- } \\
\text { value }\end{array}$ & $\begin{array}{l}\text { Reperfusi } \\
\text { on time }\end{array}$ & $\begin{array}{c}\text { p- } \\
\text { value }\end{array}$ & $\begin{array}{c}\text { interactio } \\
\mathbf{n}\end{array}$ & $\begin{array}{c}\text { p- } \\
\text { value }\end{array}$ \\
\hline WBC & 0.957451 & 0.3782 & 1.396122 & 0.0000 & 1.918237 & 0.0000 & 1.71622 & 0.0000 & 1.601887 & 0.0000 \\
\hline $\begin{array}{l}\text { RBC } \\
\text { count }\end{array}$ & 0.961059 & 0.0000 & 1.733395 & 0.0000 & 6.519657 & 0.0000 & 1.039524 & 0.0000 & 1.309673 & 0.0000 \\
\hline $\begin{array}{c}\text { Hematoc } \\
\text { rit }\end{array}$ & 38.424 & 0.0000 & 9.076658 & 0.0000 & 6.222898 & 0.0000 & 1.001356 & 0.2184 & 12.66419 & 0.0000 \\
\hline $\begin{array}{l}\text { Hemoglo } \\
\text { bin }\end{array}$ & 1.268689 & 0.0000 & 1.839035 & 0.0000 & 13.1658 & 0.0000 & 1.252422 & 0.0000 & 1.94889 & 0.0000 \\
\hline $\mathrm{MCH}$ & 151.125 & 0.0000 & 4.246814 & 0.0000 & 2.709729 & 0.0000 & 1.177347 & 0.0000 & 4.362893 & 0.0000 \\
\hline MCV & 150.8518 & 0.0000 & 4.236722 & 0.0000 & 2.704247 & 0.0000 & 1.180156 & 0.0000 & 4.352528 & 0.0000 \\
\hline $\mathrm{MCHC}$ & 3.6046103 & 0.0000 & 1.8166222 & 0.0000 & $\begin{array}{c}1.173373 \\
8\end{array}$ & 0.0000 & 3.044774 & 0.0000 & 1.2831629 & 0.0000 \\
\hline RbcDW & 3.306773 & 0.0000 & 3.023389 & 0.0000 & 2.655885 & 0.0000 & 0.2259914 & 0.0000 & 2.370353 & 0.0000 \\
\hline $\begin{array}{c}\text { Platelet } \\
\text { count }\end{array}$ & 2.42839 & 0.0000 & 6.00238 & 0.0000 & $\begin{array}{c}6.133342 \\
9\end{array}$ & 0.0000 & 3.939027 & 0.0000 & 37.62979 & 0.0000 \\
\hline MPV & 145.8532 & 0.0000 & 4.053619 & 0.0000 & 2.603947 & 0.0000 & 1.2334644 & 0.0000 & 4.164431 & 0.0000 \\
\hline $\begin{array}{l}\text { Platelet } \\
\text { DW }\end{array}$ & 0.6940233 & 0.0000 & 1.319118 & 0.0000 & 2.206972 & 0.0000 & 2.2484006 & 0.0000 & 2.458888 & 0.0000 \\
\hline Plateletcrit & 4.3251772 & 0.0000 & 1.4882359 & 0.0000 & $\begin{array}{c}0.751452 \\
56\end{array}$ & 0.0886 & 5.620077 & 0.0000 & 1.0233828 & 0.0000 \\
\hline Glucose & 156.4991 & 0.0000 & 4.53659 & 0.0000 & 2.81397 & 0.0000 & 0.9073196 & 0.0000 & 4.660603 & 0.0000 \\
\hline Urea & 158.4209 & 0.0000 & 4.50889 & 0.0000 & 2.850291 & 0.0000 & 0.9017775 & 0.0000 & 4.632148 & 0.0000 \\
\hline $\begin{array}{c}\text { Creatinin } \\
\mathrm{e}\end{array}$ & 168.9034 & 0.0000 & 4.872332 & 0.0000 & 3.039572 & 0.0000 & 1.0262016 & 0.0000 & 5.005523 & 0.0000 \\
\hline $\begin{array}{c}\text { Total } \\
\text { proteins }\end{array}$ & 155.9562 & 0.0000 & 4.421079 & 0.0000 & 2.803573 & 0.0000 & 0.8842162 & 0.0000 & 4.541934 & 0.0000 \\
\hline $\begin{array}{c}\text { Albumin } \\
\mathrm{s}\end{array}$ & 0.2457507 & 0.0073 & 0.5303472 & 0.0000 & $\begin{array}{c}0.624305 \\
2\end{array}$ & 0.0465 & 1.237477 & 0.0000 & 0.5000416 & 0.0000 \\
\hline ALT & 0.5955473 & 0.0000 & 0.86405406 & 0.0000 & 7.967324 & 0.0000 & 0.4734427 & 0.0000 & 1.6107645 & 0.0000 \\
\hline AST & 1.149264 & 0.0391 & 0.9347365 & 0.0000 & $\begin{array}{c}0.669577 \\
5\end{array}$ & 0.0000 & 0.7631082 & 0.0000 & 0.8224656 & 0.0000 \\
\hline$\gamma \mathrm{GT}$ & 1 & 1.0000 & 0.5367033 & 0.0000 & $\begin{array}{c}1.060606 \\
1\end{array}$ & 0.8982 & 2.146813 & 0.0000 & 3.7264586 & 0.0000 \\
\hline ALP & 134.0033 & 0.0000 & 3.602703 & 0.0000 & 2.349961 & 0.0000 & 0.7205412 & 0.0000 & 3.701187 & 0.0000 \\
\hline $\mathrm{ACP}$ & 2.774031 & 0.0000 & 5.450674 & 0.0000 & 7.86942 & 0.0000 & 0.121724 & 0.0000 & 8.011334 & 0.0000 \\
\hline CPK & 144.0769 & 0.0000 & 3.987264 & 0.0000 & 2.567192 & 0.0000 & 0.7974539 & 0.0000 & 4.09626 & 0.0000 \\
\hline CK-MB & 141.313 & 0.0000 & 3.883186 & 0.0000 & 2.509108 & 0.0000 & 1.2876033 & 0.0000 & 3.989339 & 0.0000 \\
\hline LDH & 142.9228 & 0.0000 & 3.944068 & 0.0000 & 2.543149 & 0.0000 & 1.2677226 & 0.0000 & 4.051881 & 0.0000 \\
\hline Sodium & 1.695709 & 0.0000 & 0.8085706 & 0.0000 & 3.008772 & 0.0455 & 1.631842 & 0.0000 & 2.74914 & 0.0000 \\
\hline $\begin{array}{c}\text { Potassiu } \\
\mathrm{m}\end{array}$ & 1.640618 & 0.0000 & 0.968488 & 0.0000 & 3.346145 & 0.0000 & 2.414214 & 0.0000 & 11.4937 & 0.0000 \\
\hline Chloride & 0.5544784 & 0.0007 & 0.8643683 & 0.0000 & 1.07745 & 0.5428 & 1.358293 & 0.0000 & 1.012762 & 0.0000 \\
\hline Calcium & $\begin{array}{c}0.0000033 \\
4 \\
\end{array}$ & 0.0000 & 0.2490068 & 0.0000 & $\begin{array}{c}0.198875 \\
3\end{array}$ & 0.0000 & 2.063208 & 0.0000 & 2.3623042 & 0.0000 \\
\hline Mean & 5.6905513 & 0.0490 & 2.1416137 & 0.0000 & $\begin{array}{c}2.393175 \\
4\end{array}$ & 0.0556 & 1.1787972 & 0.0072 & 2.4579248 & 0.0000 \\
\hline
\end{tabular}

\section{CONCLUSION}

The anti-oxidant agent U-74389G was proved having 1.823808-fold [1.806514 - 1.841268] more hypermagnesiemic effect than Epo whether all variables have been considered ( $\mathrm{p}$-value $=0.0000$ ); a trend attenuated along the short term time frame of the experiment in rats. A biochemical investigation remains about how $\mathrm{U}-74389 \mathrm{G}$ mediates in these actions. 


\section{REFERENCES}

[1] Tsompos C, Panoulis C, Toutouzas K, Zografos G, Papalois A. The Effect of the Antioxidant Drug U74389G on Magnesium Levels During Hypoxia-Reoxygenation Injury in Rats. Annals of the Russian Academy of Medical Sciences. 2015; 70 (4): 408-412.

[2] Tsompos C, Panoulis C, Toutouzas K, Zografos G, Papalois A.The effect of erythropoietin on magnesium during ischemia reperfusion injury in rats. Revista Romana de Neurologie2014;13(1):17-22.

[3] Lee MY, Yang DK, Kim SJ. Alterations of $\mathrm{Mg}^{2+}$ After Hemorrhagic Shock. Biol Trace Elem Res. 2017 Nov;180(1):120-126.

[4] Wang AF, Roitto M, Lehto T, Sutinen S, Heinonen J, Zhang G, Repo T. Photosynthesis, nutrient accumulation and growth of two Betula species exposed to waterlogging in late dormancy and in the early growing season.Tree Physiol. 2017 Jun 1;37(6):767-778.

[5] Chubanov V, Ferioli S, Gudermann T. Assessment of TRPM7 functions by drug-like small molecules. Cell Calcium. 2017 Nov;67:166-173.

[6] Reilly-O'Donnell B, Robertson GB, Karumbi A, McIntyre C, Bal W, Nishi M, Takeshima H, Stewart AJ, Pitt SJ. Dysregulated $\mathrm{Zn}^{2+}$ homeostasis impairs cardiac type-2 ryanodine receptor and mitsugumin 23 functions, leading to sarcoplasmic reticulum $\mathrm{Ca}^{2+}$ leakage.J Biol Chem. 2017 Aug 11;292(32):1336113373.

[7] Koning G, Leverin AL, Nair S, Schwendimann L, Ek J, Carlsson Y, Gressens P, Thornton C, Wang X, Mallard C, Hagberg H. Magnesium induces preconditioning of the neonatal brain via profound mitochondrial protection.J Cereb Blood Flow Metab. 2019 Jun;39(6):1038-1055.

[8] Poore LA, Hendry R, Steyl J, Pfitzer S. Perineal urethrostomy to treat obstructive urolithiasis in a captive hand-raised steenbok (<i>Raphicerus campestris</i>). J S Afr Vet Assoc. 2017 Dec 8;88(0):e1-e6.

[9] Groom KM, David AL. The role of aspirin, heparin, and other interventions in the prevention and treatment of fetal growth restriction. Am J Obstet Gynecol. 2018 Feb;218(2S):S829-S840.

[10] Wolf A, Lusczek ER, Beilman GJ. Hibernation-Based Approaches in the Treatment of Hemorrhagic Shock. Shock. 2018 Jul;50(1):14-23.

[11] Koning G, Lyngfelt E, Svedin P, Leverin AL, Jinnai M, Gressens P, Thornton C, Wang X, Mallard C, Hagberg H. Magnesium sulphate induces preconditioning in preterm rodent models of cerebral hypoxiaischemia. Int J Dev Neurosci. 2018 Nov;70:56-66.

[12] Seyama T, Kamei Y, Iriyama T, Imada S, Ichinose M, Toshimitsu M, Fujii T, Asou H. Pretreatment with magnesium sulfate attenuates white matter damage by preventing cell death of developing oligodendrocytes. J ObstetGynaecol Res. 2018 Apr;44(4):601-607.

[13] Mu YP, Huang QH, Zhu JL, Zheng SY, Yan FR, Zhuang XL, Sham JSK, Lin MJ. Magnesium attenuates endothelin-1-induced vasoreactivity and enhances vasodilatation in mouse pulmonary arteries: Modulation by chronic hypoxic pulmonary hypertension. Exp Physiol. 2018 Apr 1;103(4):604-616.

[14] Bennet L, Galinsky R, Draghi V, Lear CA, Davidson JO, Unsworth CP, Gunn AJ. Time and sex dependent effects of magnesium sulphate on post-asphyxial seizures in preterm fetal sheep. J Physiol. 2018 Dec;596(23):6079-6092.

[15] Chollat C, Sentilhes L, Marret S. Fetal Neuroprotection by Magnesium Sulfate: From Translational Research to Clinical Application.Front Neurol. 2018 Apr 16;9:247.

[16] Dhillon SK, Lear CA, Galinsky R, Wassink G, Davidson JO, Juul S, Robertson NJ, Gunn AJ, Bennet L. The fetus at the tipping point: modifying the outcome of fetal asphyxia.J Physiol. 2018 Dec;596(23):55715592.

[17] Samsonia M, Kandelaki M, Baratashvili N. EVALUATION OF NEUROPROTECTIVE ACTIVITY OF COMPLEX IMPACT OF MAGNESIUM OF SULFATE, LAMOTRYGINE AND NACETYLCYSTEINE UNDER CONDITIONS OF COMBINED NORMOBARIC HYPOXIA WITH LIGATION OF RIGHT CAROTID ARTERY IN RATS.Georgian Med News. 2018 May;(278):172-177.

[18] Meloni BP, Campbell K, Knuckey NW. The use of magnesium in experimental cerebral ischemia. Magnesium in the Central Nervous System [Internet]. Adelaide (AU): University of Adelaide Press; 2011.

[19] Ogunyemi D, Jovanovski A, Liu J, Friedman P, Sugiyama N, Creps J, Madan I. The Contribution of Untreated and Treated Anxiety and Depression to Prenatal, Intrapartum, and Neonatal Outcomes.AJP Rep. $2018 \mathrm{Jul} ; 8(3)$ :e146-e157.

[20] Kumar V, Vogelsang L, Seidel T, Schmidt R, Weber M, Reichelt M, Meyer A, Clemens S, Sharma SS, Dietz KJ. Interference between arsenic-induced toxicity and hypoxia.Plant Cell Environ. 2019 Feb;42(2):574-590. 
[21] Daher I, Le Dieu-Lugon B, Lecointre M, Dupré N, Voisin C, Leroux P, Dourmap N, Gonzalez BJ, Marret $\mathrm{S}$, Leroux-Nicollet I, Cleren C. Time- and sex-dependent efficacy of magnesium sulfate to prevent behavioral impairments and cerebral damage in a mouse model of cerebral palsy.Neurobiol Dis. 2018 Dec;120:151-164.

[22] Liu Y, Jiang Y, Zhang M, Tang Z, He M, Bu W. Modulating Hypoxia via Nanomaterials Chemistry for Efficient Treatment of Solid Tumors.Acc Chem Res. 2018 Oct 16;51(10):2502-2511.

[23] Chollat C, Sentilhes L, Marret S. Protection of brain development by antenatal magnesium sulphate for infants born preterm.Dev Med Child Neurol. 2019 Jan;61(1):25-30.

[24] Plush K, Weaver A, Staveley L, van Wettere W. Maternal Magnesium Sulfate Supplementation in a PreFarrow Diet Improves Factors Important for Piglet Viability.Animals (Basel). 2018 Oct 22;8(10). pii: E185.

[25] Dumanska H, Veselovsky N. Short-term hypoxia induces bidirectional pathological long-term plasticity of neurotransmission in visual retinocollicular pathway.ExpEyeRes. 2019 Feb;179:25-31.

[26] Bagheri G, Rezaee R, Tsarouhas K, Docea AO, Shahraki J, Shahriari M, Wilks MF, Jahantigh H, Tabrizian K, Moghadam AA, Bagheri S, Spandidos DA, Tsatsakis A, Hashemzaei M. Magnesium sulfate ameliorates carbon monoxide-induced cerebral injury in male rats.Mol Med Rep. 2019 Feb;19(2):10321039.

[27] Lisukha LM, Stepanova YI, Kolpakov IY, Podrushnyak AY. ELECTROLYTE CONTENT IN SALIVA OF CHILDREN WITH DEVIATION IN VEGETATIVE STATUS RESIDING AT RADIOACTIVELY CONTAMINATED TERRITORIES OF UKRAINE AFTER APPLICATION OF INTERMITTENT NORMOBARIC HYPOXIA.Probl Radiac Med Radiobiol. 2018 Dec;23:359-372.

[28] Adam GO, Lee HR, Lee SJ, Kim SJ, Kim GB, Kang HS. Effects of acute lipopolysaccharide-induced toxemia model on some neglected blood parameters.Pol J VetSci. 2018 Dec;21(4):665-671.

[29] Li T, Luo XJ, Wang EL, Li NS, Zhang XJ, Song FL, Yang JF, Liu B, Peng J. Magnesium lithospermate B prevents phenotypic transformation of pulmonary arteries in rats with hypoxic pulmonary hypertension through suppression of NADPH oxidase.Eur J Pharmacol. 2019 Mar 15;847:32-41.

[30] Pradhan T, Rijal P, Rai R, Bhatta RD, Thapa BD, Regmi MC. Adverse Maternal and Fetal Outcome in Patients with Eclampsia. J Nepal Health Res Counc. 2019 Jan 28;16(41):425-427.

[31] Lin P, Wu M, Qin J, Yang J, Ye C, Wang C. Magnesiumlithospermate B improves renal hemodynamics and reduces renal oxygen consumption in 5/6th renal ablation/infarction rats. BMC Nephrol. 2019 Feb $12 ; 20(1): 49$.

[32] Xu L, Willumeit-Römer R, Luthringer-Feyerabend BJC. Effect of magnesium-degradation products and hypoxia on the angiogenesis of human umbilical vein endothelial cells.Acta Biomater. 2019 Oct 15;98:269-283.

[33] Li T, Peng JJ, Wang EL, Li NS, Song FL, Yang JF, Luo XJ, Liu B, Peng J. Magnesium Lithospermate B Derived from Salvia miltiorrhiza Ameliorates Right Ventricle Remodeling in Pulmonary Hypertensive Rats via Inhibition of NOX/VPO1 Pathway.Planta Med. 2019 Jul;85(9-10):708-718.

[34] Solevåg AL, Schmölzer GM, Cheung PY. Novel interventions to reduce oxidative-stress related brain injury in neonatal asphyxia.Free Radic Biol Med. 2019 Oct;142:113-122.

[35] Xing J, Wang M, Hong J, Gao Y, Liu Y, Gu H, Dong J, Li L. TRPM7 channel inhibition exacerbates pulmonary arterial hypertension through MEK/ERK pathway.Aging (Albany NY). 2019 Jun 19;11(12):4050-4065.

[36] Lingam I, Meehan C, Avdic-Belltheus A, Martinello K, Hristova M, Kaynezhad P, Bauer C, Tachtsidis I, Golay X, Robertson NJ. Short-term effects of early initiation of magnesium infusion combined with cooling after hypoxia-ischemia in term piglets. Pediatr Res. 2019 Jul 29.

[37] Wagner S, Steinbeck J, Fuchs P, Lichtenauer S, Elsässer M, Schippers JHM, Nietzel T, Ruberti C, Van Aken O, Meyer AJ, Van Dongen JT, Schmidt RR, Schwarzländer M. Multiparametric real-time sensing of cytosolic physiology links hypoxia responses to mitochondrial electron transport.New Phytol. 2019 Dec;224(4):1668-1684.

[38] Mi F, Liu F, Zhang C. Magnesium protects mouse hippocampal HT22 cells against hypoxia-induced injury by upregulation of miR-221.J Cell Biochem. 2019 Sep 12.

[39] El Farargy MS, Soliman NA. A randomized controlled trial on the use of magnesium sulfate and melatonin in neonatal hypoxic ischemic encephalopathy. J Neonatal Perinatal Med. 2019 Sep 8.

[40] Xu L, Willumeit-Römer R, Luthringer-Feyerabend B. Hypoxia influences the effects of magnesium degradation products on the interactions between endothelial and mesenchymal stem cells. Acta Biomater. 2019 Oct 14. pii: S1742-7061(19)30694-4. 
[41] Tsompos C, Panoulis C, Toutouzas K, Triantafyllou A, Zografos G C, Tsarea K, Karamperi M, Papalois A. Comparison of the Hypochloremic Effects of Erythropoietin and U-74389G. GMJ Medicine. 2019; 3: 156- 163.

[42] Tsompos C, Panoulis C, Toutouzas K, Triantafyllou A, Zografos CG, Tsarea K, Karamperi M, Papalois A. Comparison of the Hypocalcemic Effects of Erythropoietin and U-74389G. Clin Res Hematol 2019;2(2):1-8.

Citation: TsomposConstantinos,et.al., " Comparison of the Magnesium Alterations after Erythropoietin and U-74389G Process" International Journal of Research Studies in Microbiology and Biotechnology (IJRSMB), vol. 5, no. 4, pp. 17-25, 2019. Available: DOI: http://dx.doi.org/ 10.20431/2454-9428.0504004

Copyright: () 2019 Authors. This is an open-access article distributed under the terms of the Creative Commons Attribution License, which permits unrestricted use, distribution, and reproduction in any medium, provided the original author and source are credited. 